\title{
Percent Mass per Volume
}

National Cancer Institute

\section{Source}

National Cancer Institute. Percent Mass per Volume. NCI Thesaurus. Code C48527.

A unit of percentage concentration expressed as a fraction of a component by mass in the entire volume of a resulting mixture. The standard conditions for temperature and pressure apply. The mass-volume percentage is used for liquid solute/solution systems and systems containing solid phase components. The concept also refers to the weightvolume percentage concentration given that standard values for specific gravity of the solute are used. 